\title{
The Association of T45G Polymorphism in the Adiponectin Gene with Some Hormonal Parameters in Iraqi Women with Polycystic Ovary Syndrome
}

\author{
Raghad Ayad Majeed ${ }^{1}$, Adel Fawzi Shihab ${ }^{2}$, Akeel Hussein AL-Assei \\ ${ }^{1}$ Assistant Lecturer, ${ }^{2}$ Prof., Department of Biology, College of Science, Tikrit University, Iraq
}

\begin{abstract}
This study was reflected on the correlations between the polycystic ovary syndrome (PCOS) and a Single Nucleotide Polymorphism (SNP) T45G in the adiponectin gene among Iraqi infertile women with polycystic ovary syndrome. Eighty primary infertile women with PCOS, sixty-two secondary infertile women with PCOS and 50 healthy fertile women in Iraq were included in this study, Blood samples were collected from the infertility clinic in Azadi Teaching Hospital and AL-Salam Hospital. The age of infertile and fertile women was ranged from 18 to 46 years. Results showed association between T45G polymorphism in the adiponectin gene and infertile PCOS women. Moreover, infertile women with PCOS with these polymorphisms have been reported to have higher LH, FSH and prolactin concentrations and BMI. In conclusion $45 \mathrm{~T} \rightarrow \mathrm{G}$ polymorphisms have been shown to be associated with an increased risk of PCOS women with PCOS with these polymorphisms have been reported to have higher LH, FSH and prolactin concentrations and BMI.
\end{abstract}

Keywords: Adiponectin, adipokines, PCOS.

\section{Introduction}

Polycystic ovarian syndrome (PCOS) is one of the most common causes of ovulatory infertility affects $4-12 \%$ of women in reproductive age ${ }^{[1]}$. The exact cause of PCOS is unknown, in some cases it may be a familial disorder, but the genetic basis of the syndrome remains unclear ${ }^{[2]}$. Adiponectin (APN) is described as a 'beneficial' adipokine in reproduction, both adiponectin receptors ADIPOR1 and ADIPOR2 are expressed in human hypothalamus and pituitary ${ }^{[3]}$. The human adiponectin gene was localized to chromosome $3 \mathrm{q} 27$, a region highlighted as a genetic susceptibility locus for type 2 diabetes and metabolic syndrome ${ }^{[4]}$. The major action of APN is to increase insulin sensitivity by stimulating glucose uptake in the liver and muscle, decreasing hepatic gluconeogenesis. It has been shown that adiponectin inhibits LH and GNRH release ${ }^{[5]}$. At physiological levels, adiponectin induces the expression of genes associated with periovulatory remodeling of the ovarian follicle in porcine granulose cells ${ }^{[6]}$ suggest that APN may play an active role in ovulation. Moreover, a number of studies investigated the association of PCOS with polymorphisms of the APN gene ${ }^{[7]}$ recently found a significant association of APN T45G polymorphism with PCOS by a meta-analysis. As the most abundant adipokine in the human body, APN seems to play an important role in the pathogenesis of PCOS. The aim of the present study was to assess the influence of Evaluation luteinizing hormone (LH), follicle-stimulating hormone (FSH), testosterone (T) and Prolactin (PRL) among Iraqi infertile women with polycystic ovary syndrome and possible correlations with $\mathrm{T} 45 \mathrm{G}$ polymorphism in the adiponectin gene.

\section{Materials and Method}

This study included 192 samples were taken from women, who were diagnosed with polycystic ovarian syndrome based on the criteria proposed by[8]. The study has included two main patients groups :

1. Eighty primary infertile women with PCOS.

2. Sixty two secondary infertile women with PCOS. 
Their ages ranged between (18-46) years old referred to infertility clinic in Azadi Teaching Hospital and AL-Salam Hospital in Iraq. A total of 50 healthy females participated in the study. Control individuals were healthy volunteers or endocrinology outpatients without any endocrine related diseases except for simple overweight/obesity. Body mass index (BMI) was calculated as weight in $\mathrm{kg}$ divided by (height) 2 in $\mathrm{m} 2$. In the 2 nd day of menstrual cycle after Venous blood sample $(5 \mathrm{ml})$ was collected from control and patients groups, Each blood sample was divided into two tubes as follows: Serum tubes used for hormonal and biochemical testes and another tubes containing the anticoagulant acid citrate dextrose (ACD) for molecular analysis.

Hormonal analysis For FSH, LH, T and PRL in serum was determined by using commercially available enzyme-linked immunosorbent assay (ELISA) kits (bioactiva diagnostic, Germany).

Genotype Analysis: Genomic DNA of 192 samples were extracted from whole blood of women with PCOS and the controls ${ }^{[9]}$. The adiponectin $45 \mathrm{TG}$ polymorphism was genotyped by amplification of genomic DNA using the following primers: forward, 5'-TAG AAG TAG ACT CTG CTG AGA TG-3' was chosen as the forward primer and 5'-CTC CCT GTG TCT AGG CCT TAG-3' ${ }^{[10]}$. A $423 \mathrm{bp}$ band was observed for the adiponectin gene after PCR amplified.The product was digested with SmaI (New England BioLabs Inc.) and the digestion products were resolved by electrophoresis in a 3\% agarose gel, Examination of the bands occurring after development of the cleavage products on the gel revealed a $423 \mathrm{bp}$ band for the TT genotype in individuals with the wild-type genotype, 265 and $158 \mathrm{bp}$ bands for the GG genotype in individuals with homozygous mutant genotypes and 423, 265 and $158 \mathrm{bp}$ bands were observed in individuals with heterozygous genotypes ${ }^{[10]}$.

Statistical Analysis Data: Statistical analysis was performed using Statistical Package for the Social Sciences software (Mini-tab version 17). All data were presented as mean \pm S.D (standard deviation). Paired T test were used to compare between means of variables between groups, Genotype and allelic frequencies were compared between the groups by chi-squared test. Logistic regression analysis was applied by using F-Test to find out if the means among populations are significantly different by applied Duncan's multiple range test. A p value less than 0.05 was considered statistically significant.

\section{Results and Discussion}

The results of hormonal study were as follows as shown in the table (1):

- There is significant $(\mathrm{P}<0.05)$ decrease in FSH levels in the infertile PCOS women groups than in healthy fertile women.

- There is significant $(\mathrm{P}<0.05)$ increase in $\mathrm{LH}$, prolactin, testosterone levels in the infertile PCOS women groups than in healthy fertile women.

The table (1) showed also significantly higher $\mathrm{P} \leq$ $0.05 \mathrm{BMI}$ among women with primary infertility than in women with secondary infertility and control groups.

Table (1): Baseline characteristics of the primary and secondary infertile women with PCOS and the control groups

\begin{tabular}{|l|c|c|c|c|}
\hline Parameters & $\begin{array}{c}\text { Primary infertile women } \\
\text { with PCOS N=80 }\end{array}$ & $\begin{array}{c}\text { Secondary infertile women } \\
\text { with PCOS N= 62 }\end{array}$ & Control N=50 & P-value \\
\hline LH $(\mathrm{mlU} / \mathrm{ml})$ & $13.40 \pm 0.159$ & $17.70 \pm 1.85$ & $5.457 \pm 0.058$ & $\leq 0.05$ \\
\hline FSH $(\mathrm{mlU} / \mathrm{ml})$ & $4.056 \pm 0.061$ & $4.671 \pm 0.099$ & $5.809 \pm 0.148$ & $\leq 0.05$ \\
\hline Prolactin $(\mathrm{ng} / \mathrm{ml})$ & $15.95 \pm 0.55$ & $22.98 \pm 0.20$ & $10.68 \pm 0.359$ & $\leq 0.05$ \\
\hline Testosterone $(\mathrm{ng} / \mathrm{ml})$ & $2.1450 \pm 0.181$ & $1.0978 \pm 0.076$ & $0.3869 \pm 0.011$ & $\leq 0.05$ \\
\hline BMI $\left(\mathrm{Kg} / \mathrm{m}^{2}\right)$ & $34.338 \pm 1.089$ & $30.097 \pm 0.661$ & $23.241 \pm 1.101$ & $\leq 0.05$ \\
\hline
\end{tabular}


Products of PCR of Adiponectin gene for all patients and control groups were analyzed on agarose gels figure (1). The PCR product of $423 \mathrm{bp}$ was treated with the restriction enzyme Sma-I, The bands occurring after development of the cleavage products on the gel revealed a $423 \mathrm{bp}$ band for the TT genotype in individuals with the wild-type genotype, 265 and 158 bp bands for the GG genotype in individuals with homozygous mutant genotypes and 423, 265 and 158 bp bands were observed in individuals with heterozygous genotypes (TG) (Figure 2).

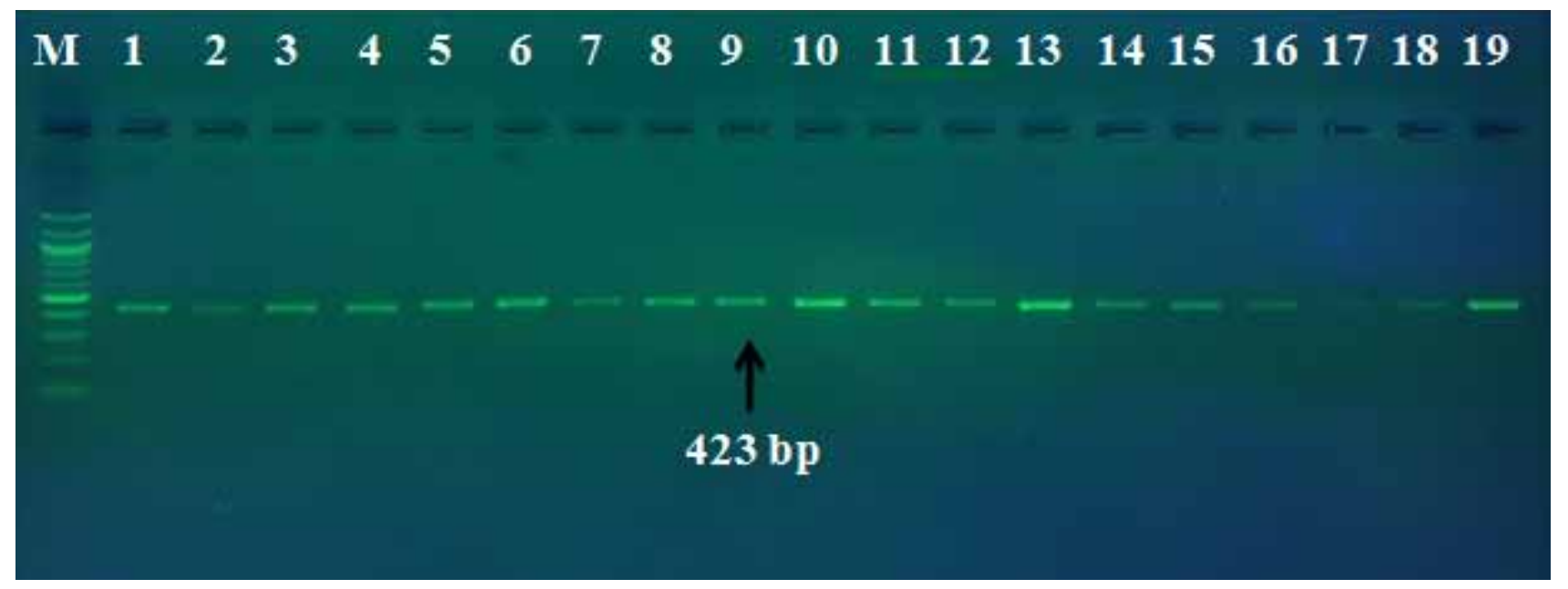

Figure (1) : PCR amplification products of adiponectin gene on $2 \%$ agarose gel

Lane M : DNA ladder (100 bp)

Lane (1 to 19) : PCR amplification products 423 bp for adiponectin gene for study groups samples

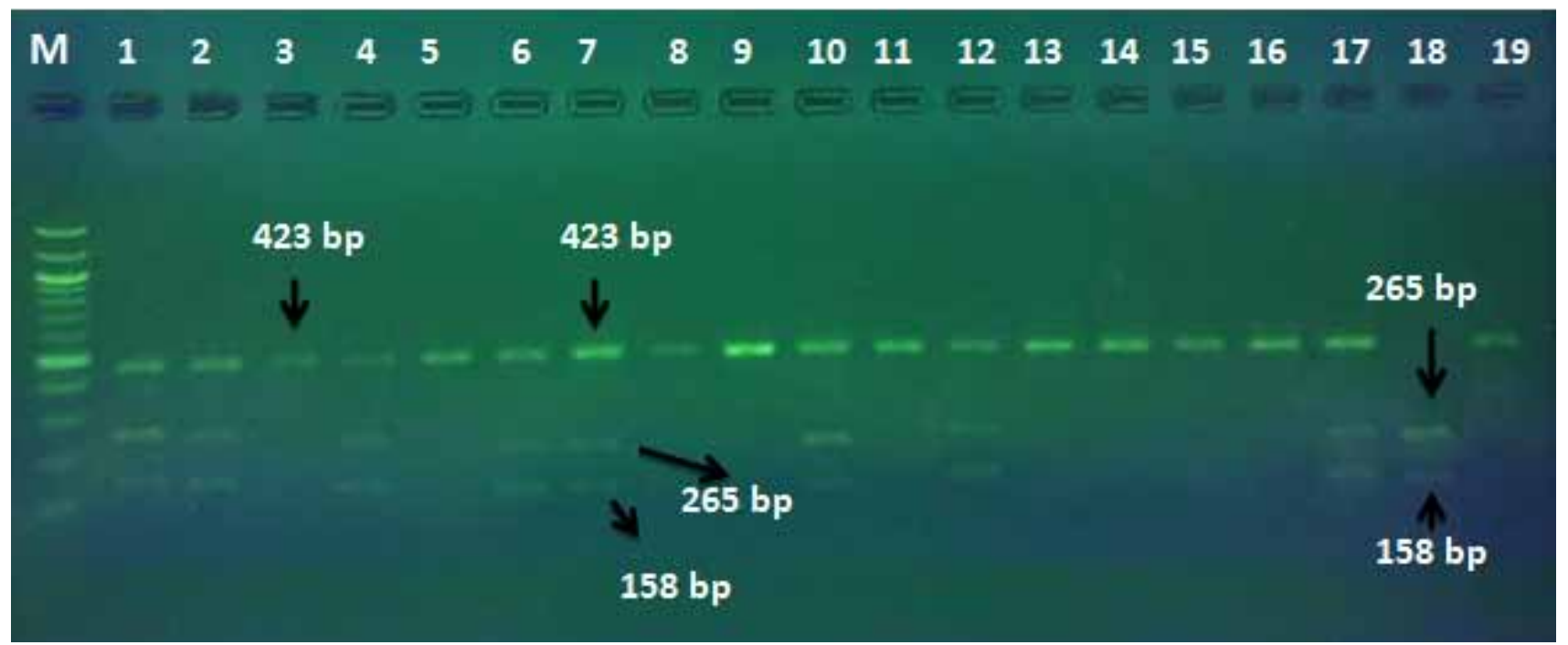

Figure (2) : Gel electrophoresis of PCR products (Adiponectin) for healthy and patients groups digested with Sma-I restriction enzyme on $3 \%$ agarose.

Lane M : DNA ladder (100 bp)

Lane $(3,5,8,9,11,13,14,15,16)$ : The normal homozygote genotype (TT) bands after digestion with Sma-I with molecular size 423 bp Lane (18) : The mutant homozygote genotype (GG) bands after digestion with Sma-I with molecular size $265 \mathrm{bp}, 158 \mathrm{bp}$.

Lane $(1,2,4,6,7,10,12,17,19)$ : The mutant heterozygote (TG) bands after digestion with Sma-I with the molecular size 423 bp, 265 bp and $158 \mathrm{bp}$. 
Table (2): The observed and expected numbers and allele frequencies for Adiponectin gene in the study groups

\begin{tabular}{|c|c|c|c|c|c|}
\hline Groups & Genotype & Observed Number & Expected Number & $\mathbf{X}^{2}$ & P-value \\
\hline \multirow{3}{*}{ Control } & TT & 45 & 40.5 & \multirow{6}{*}{$X^{2}=50$, d.f. $=2$} & \multirow{6}{*}{$\leq 0.001$} \\
\hline & GG & 5 & 0.5 & & \\
\hline & TG & 0 & 0.18 & & \\
\hline Total & \multicolumn{3}{|c|}{50} & & \\
\hline Frequency of $\mathrm{T}$ allele & 0.9 & & & & \\
\hline Frequency of $\mathrm{G}$ allele & 0.1 & & & & \\
\hline \multirow{4}{*}{$\begin{array}{l}\text { Primary infertile women } \\
\text { with PCOS group }\end{array}$} & Genotype & Observed number & Expected number & \multirow{7}{*}{$X^{2}=11.56$, d.f. $=2$} & \multirow{7}{*}{$\leq 0.01$} \\
\hline & TT & 52 & 46.5 & & \\
\hline & GG & 10 & 4.5 & & \\
\hline & TG & 18 & 29.04 & & \\
\hline Total & \multicolumn{3}{|c|}{80} & & \\
\hline Frequency of T allele & 0.762 & & & & \\
\hline Frequency of $\mathrm{G}$ allele & 0.238 & & & & \\
\hline \multirow{4}{*}{$\begin{array}{l}\text { Secondary infertile women } \\
\text { with PCOS group }\end{array}$} & Genotype & Observed number & Expected number & \multirow{7}{*}{$X^{2}=2.77$, d.f. $=2$} & \multirow{7}{*}{ NS } \\
\hline & TT & 38 & 35.6 & & \\
\hline & GG & 6 & 3.6 & & \\
\hline & TG & 18 & 22.8 & & \\
\hline Total & \multicolumn{3}{|c|}{62} & & \\
\hline Frequency of T allele & 0.758 & & & & \\
\hline Frequency of $\mathrm{G}$ allele & 0.242 & & & & \\
\hline
\end{tabular}

*d.f : degree freedom; $* * \mathrm{P} \leq 0.001 ; * \mathrm{P} \leq 0.01 ; \mathrm{NS}$ : No significant

The study of the adiponectin gene polymorphism at the location +45 in exon 2 has indicated the presence of two alleles (T and $\mathrm{G})$ gene and three genotypes (TT, GG, TG) which shown a difference in the allelic frequency table (2) among the community of Patients, Whereas Healthy women were shown only two genotypes (TT and GG). There was a difference in the P-value between the observed and expected numbers among control group for adiponectin gene, Also primary infertile women with PCOS group were showed high statistically significant difference $\left(\mathrm{X}^{2}=11.56, \mathrm{P}<0.05\right)$ between the observed and expected numbers among their cases group for adiponectin gene. Whereas no significant difference was detected $\left(\mathrm{X}^{2}=2.77, \mathrm{P}=0.05\right)$ between the observed and expected numbers among secondary infertile women with PCOS group. That's mean the primary infertile women with PCOS group were not subjected to hardy Weinberg equilibrium when compared with control group. When the community study where not subjected to hardy Weinberg equilibrium that referred the evolution occurred and there was at least one powerful evolution change (may be under mutation effect) lead to occurred disequilibrium that disturbed the stability of the cases study and effect on the community structure and it's allele frequency ${ }^{[11]}$. The results showed there is a correlation ship between adiponectin gene SNP rs2241766 polymorphisms (T45G) in exon 2 and primary infertile women with PCOS.

The results of the present study agreement with the case-control study of ${ }^{[12]}$ in that showed significant association between the ADIPOQ $45 \mathrm{~T} \rightarrow \mathrm{G}$ polymorphism and risk of polycystic ovary syndrome (PCOS) and the appearance of the allele G increased this risk $^{[13]}$. Whereas disagreed with the study performed in Greek women, no significant difference was detected between $45 \mathrm{~T} \rightarrow \mathrm{G}$ polymorphism frequencies in the PCOS and control groups and this polymorphism at position $45 \mathrm{~T} \rightarrow \mathrm{G}$ had not been associated with a risk for development of PCOS.

The results in the table (3) showed that the primary infertile women with PCOS group carrying the TG genotype significantly higher $\mathrm{FSH}$, prolactin levels and BMI $(p \leq 0.05$ than in those with the TT and GG 
genotypes. In patients with secondary infertility with PCOS group exhibiting the GG genotype, observed a higher LH level with statistical significance $(p \leq 0.05)$ than in those with the TT and TG genotypes and patients carrying the TG genotype significantly higher BMI with statistical significance $(p \leq 0.05)$.

Table (3) : Mean ( \pm SD) clinical biochemical parameters and BMI levels with the (TT, GG, TG) genotypes of the adiponectin gene in the control, primary and secondary infertile women with PCOS group

\begin{tabular}{|c|c|c|c|c|c|c|c|c|c|c|c|}
\hline \multirow[b]{3}{*}{ Parameters } & \multicolumn{2}{|c|}{ Control group } & \multirow{3}{*}{ P-value } & \multicolumn{3}{|c|}{$\begin{array}{l}\text { Primary infertile women with } \\
\text { PCOS group genotype }\end{array}$} & \multirow{3}{*}{ p- value } & \multicolumn{3}{|c|}{$\begin{array}{l}\text { Secondary infertile women } \\
\text { with PCOS group genotype }\end{array}$} & \multirow{3}{*}{ p-value } \\
\hline & TT & GG & & TT & GG & TG & & TT & GG & TG & \\
\hline & $\begin{array}{c}\text { Mean } \pm \\
\text { SD }\end{array}$ & $\begin{array}{c}\text { Mean } \pm \\
\text { SD }\end{array}$ & & $\begin{array}{c}\text { Mean } \pm \\
\text { SD }\end{array}$ & $\begin{array}{c}\text { Mean } \pm \\
\text { SD }\end{array}$ & $\begin{array}{c}\text { Mean } \pm \\
\text { SD }\end{array}$ & & $\begin{array}{c}\text { Mean } \pm \\
\text { SD }\end{array}$ & $\begin{array}{c}\text { Mean } \pm \\
\text { SD }\end{array}$ & $\begin{array}{c}\text { Mean } \pm \\
\text { SD }\end{array}$ & \\
\hline LH & $\begin{array}{c}5.28 \pm \\
2.35\end{array}$ & $\begin{array}{c}5.55 \pm \\
1.50\end{array}$ & NS & $\begin{array}{c}14.65 \pm \\
8.29\end{array}$ & $\begin{array}{c}15.38 \pm \\
7.90\end{array}$ & $\begin{array}{c}10.63 \pm \\
8.81\end{array}$ & NS & $\begin{array}{c}17.751 \pm \\
1.312\end{array}$ & $\begin{array}{c}23.123 \pm \\
3.302\end{array}$ & $\begin{array}{c}13.780 \pm \\
1.906\end{array}$ & $0.045^{*}$ \\
\hline FSH & $\begin{array}{c}5.60 \pm \\
1.88\end{array}$ & $\begin{array}{c}6.22 \pm \\
1.75\end{array}$ & NS & $\begin{array}{c}3.931 \pm \\
2.540\end{array}$ & $\begin{array}{c}2.674 \pm \\
1.789\end{array}$ & $\begin{array}{c}4.741 \pm \\
2.644\end{array}$ & $0.052^{*}$ & $\begin{array}{c}4.474 \pm \\
0.447\end{array}$ & $\begin{array}{c}6.243 \pm \\
1.125\end{array}$ & $\begin{array}{c}4.727 \pm \\
0.650\end{array}$ & NS \\
\hline Prolactin & $\begin{array}{c}9.84 \pm \\
6.00\end{array}$ & $\begin{array}{c}8.91 \pm \\
5.75\end{array}$ & NS & $\begin{array}{c}11.05 \pm \\
14.47\end{array}$ & $\begin{array}{c}25.04 \pm \\
17.45\end{array}$ & $\begin{array}{c}15.59 \pm \\
12.09\end{array}$ & $0.019^{*}$ & $\begin{array}{c}21.397 \pm \\
2.091\end{array}$ & $\begin{array}{c}20.460 \pm \\
5.262\end{array}$ & $\begin{array}{c}26.596 \pm \\
3.038\end{array}$ & NS \\
\hline Testosterone & $\begin{array}{c}0.406 \pm \\
0.261\end{array}$ & $\begin{array}{c}0.266 \pm \\
0.117\end{array}$ & NS & $\begin{array}{c}2.222 \pm \\
1.374\end{array}$ & $\begin{array}{c}1.906 \pm \\
1.316\end{array}$ & $\begin{array}{c}2.191 \pm \\
1.524\end{array}$ & NS & $\begin{array}{c}1.222 \pm \\
0.161\end{array}$ & $\begin{array}{c}0.908 \pm \\
0.406\end{array}$ & $\begin{array}{c}0.883 \pm \\
0.234\end{array}$ & NS \\
\hline BMI & $\begin{array}{c}23.42 \pm \\
2.60\end{array}$ & $\begin{array}{c}24.56 \pm \\
2.88\end{array}$ & NS & $\begin{array}{c}28.406 \pm \\
4.811\end{array}$ & $\begin{array}{c}31.350 \pm \\
3.131\end{array}$ & $\begin{array}{c}32.360 \pm \\
4.48\end{array}$ & $0.005^{*}$ & $\begin{array}{c}29.87 \pm \\
0.723\end{array}$ & $\begin{array}{c}24.95 \pm \\
1.821\end{array}$ & $\begin{array}{c}34.58 \pm \\
1.051\end{array}$ & $0.001^{*}$ \\
\hline
\end{tabular}

$* \mathrm{P} \leq 0.05 ; \mathrm{NS}:$ No significant

In human, adiponectin was present mainly in growth hormone $(\mathrm{GH})$, follicle-stimulating hormone (FSH), luteinising hormone (LH) and thyroid stimulating hormone (TSH) producing cells, whereas adiponectin receptors were located in the gonadotrophs, somatotrophs and thyrotrophs, but not in corticotrophs or lactotrophs ${ }^{[14]}$. The presence of adiponectin and its receptors in the ovaries during all periods of the estrous cycle, make Adiponectin plays a key role in oocyte maturation, granulosa cell proliferation and steroid secretion through its impact on genes important for ovarian follicular development and ovarian reserve ${ }^{[15]}$.

The presence of adiponectin receptors in the GnRH neurons and pituitary cells and its influence on the GnRH, LH and FSH release suggests an important role of adiponectin at the hypothalamic-pituitary axis in the control of fertility in female by regulating the activity of hypothalamic-pituitary axis, because its deficiency disrupts FSH and LH secretion as well as LH surge. Adiponectin mutation also causes significant reduction in GnRH immunoreactive neurons, which helps explain the disrupted estrous cyclicity and ovarian functions ${ }^{[16]}$.

Women with PCOS has shown that adiponectin messenger RNA (mRNA) expression is significantly lower in women with PCOS compared with weightmatched women without PCOS, This decreased expression, occurs in both subcutaneous and visceral fat tissue $^{[17]}$. For more, adiponectin increased the expression of PPARA and peroxisome proliferator-activated receptor gamma coactivator 1-alpha genes involved in the regulation of energy homeostasis, especially fatty acid oxidation and carbohydrate metabolism ${ }^{[18]}$ and that may be elucidated BMI value in the PCOS groups in the present .

According to this observation in the ${ }^{[19]}$ in women with PCOS, possibly as the result of high levels of androgens, adiponectin receptors are upregulated in both subcutaneous and visceral fats, this may be a compensatory mechanism to achieve some insulin sensitivity and that deals with this study.

\section{Conclusion}

In conclusion $45 \mathrm{~T} \rightarrow \mathrm{G}$ polymorphisms have been shown to be associated with an increased risk of PCOS, women with PCOS with these polymorphisms have been reported to have higher $\mathrm{LH}, \mathrm{FSH}$ and prolactin concentrations and BMI. 


\section{Conflict of Interest: None}

Funding: Self

Ethical Clearance: Not required

\section{References}

1. Majumdar A, Singh TA. Comparison of clinical features and health manifestations in lean vs obese Indian women with polycystic ovarian syndrome. J Hum Reprod Sci. 2009,2:12-7.

2. El Hayck S, Bitar L, Hamdar LH, Mirza FG, Daud G. Polycystic ovarian syndrome: An updated overview. Front.physiol. 2016, 7:124.

3. Kubota N, Yano W, Kubota T, Yamauchi T, Itoh S, Kumagai H, Kozono H, Takamoto I, Okamoto S, Shiuchi T. Adiponectin stimulates AMP-activated protein kinase in the hypothalamus and increases food intake. Cell Metabolism, 2007. 6:55-68.

4. Kissebah AH, Sonnenberg GE, Myklebust J, Goldstein M, Broman K, James RG, Marks JA, Krakower GR, Jacob HJ, Weber J, Martin L, Blangero J, Comuzzie AG. Quantitative trait loci on chromosomes 3 and 17 influence phenotypes of the metabolic syndrome. Proc Natl Acad Sci USA, 2000. 97:14478-14483

5. Wen JP, Lv WS, Yang J, Nie AF, Cheng XB, Yang Y, Ge Y, Li XY, Ning G. Globular adiponectin inhibits GnRH secretion from GT1-7 hypothalamic GnRH neurons by induction of hyperpolarization of membrane potential. Biochemical and Biophysical Research Communications, 2008. 371 :756-761.

6. Ledoux S, Campos DB, Lopes FL, Dobias-Goff M, Palin MF. Adiponectin induces periovulatory changes in ovarian follicular cells. Endocrinology. 2006. $1475178-5186$.

7. Mahdi WKM, Mohammed MS, Sanad AS. Association of polycystic Ovary Syndrome and adiponectin Gene Polymorphism. Arch.Clin. Microbiol, 2016. 7(3): 20.

8. Rotterdam ESHRE/ASRM-Sponsored PCOS Consensus workshop group. Revised 2003 consensus on diagnostic criteria and long-term health risk related to polycystic ovary syndrome (PCOS). Hum.Reprod, 2004. 19: 41-47.

9. Ali SM, Mahnaz S, Mahmood T. Rapid genemic DNA extraction (RGDE0. Forensic sciences international: Genetics supplement series, 2008. $1(1): 5-63$.
Medico-legal Update, April-June 2020, Vol. 20, No. 2

779

10. Demirci H, Yilmaz M, Ergun MA, Yurtcu E, Bukan N, Ayvaz G. Frequency of adiponectin gene polymorphism ovary syndrome and the association with serum adiponectin androgen levels, insulin resistance and clinical parameters. Gynecological endocrinology, 2010. 26(5):348-355 .

11. Snustad DP, Simmons MJ. Genetics. $6^{\text {th }}$ edn., John Wiley and Sons, Inc. 2012.

12. Marioli DJ, Koika V, Adonakis GL, Saltamavros AD, Karela A. No association of the G972S polymorphism of the insulin receptor substrate-1 gene with polycystic ovary syndrome in lean PCOS women with biochemical hyperandrogenemia. Arch Gynecol Obstet. 2010. 281: 1045-1049.

13. Ranjzad F, Mahmoudi T, Irani SA, Mahban A, Nikzamir A. A common variant in the adiponectin gene and polycystic ovary syndrome risk. Mol Biol Rep. 2012. 39: 2313-2319.

14. Psilopanagioti A, Papadaki H, Kranioti EF, Alexandrides TK, Varakis JN. Expression of adiponectin and adiponectin receptors in human pituitary gland and brain. Neuroendocrinology. 2009. 89 38-47.

15. Merhi Z, Bazzi A, Bonney E, Buyuk E. Role of adiponectin in ovarian follicular development and ovarian reserve. Biomedical Reports. 2019. doi:10.3892/br.2019.1213.

16. Cheng L, Shi H, Jin Y, Li X, Pan J, Lai Y, Lin Y, Jin Y, Roy G, Zhao A. Adiponectin Deficiency Leads to Female Subfertility and Ovarian Dysfunctions in Mice. Endocrinology, 2016. 157, 4875-4887.

17. Carmina E, Chu MC, Moran C, Tortoriello D, Vardhana P, Tena G, Lobo R, Preciado R. Subcutaneous and omental fat expression of adiponectin and leptin in women with polycystic ovary syndrome. Fertility \& Sterility, 2008. 89:642-648.

18. Shehzad A, Iqbal W, Shehzad O, Lee Y. Adiponectin: Regulation of its production and its role in human diseases. HORMONES, 2012. 11(1):8-20.

19. Tan BK, Chen J, Digby JE, Keay SD, Kennedy CR, Randeva HS. Upregulation of adiponectin receptor 1 and 2 mRNA and protein in adipose tissue and adipocytes in insulin-resistant women with polycystic ovary syndrome. Diabetologia, 2006. 49: $2723-272$ 